\title{
Pengaruh Iklim Organisasi Terhadap Efektivitas Pelayanan Pegawai Kantor Camat Kota Utara Kota Gorontalo
}

\author{
Rahmisyari \\ Fakultas Ekonomi Univeristas Ichsan gorontalo \\ persadalestari@yahoo.co.id
}

\begin{abstract}
The Effect of Organizational Climate on the Effectiveness of Employee Services at the North Kota Camat Office, Gorontalo City, The purpose of this study was to determine and analyze the Effect of Organizational Climate on the Effectiveness of Employee Services. This study used a sample of 33 respondents, the questionnaire was used as a primary data collection tool and the data were analyzed using a path analysis tool Based on the results of this study that the organizational climate consisting of Responsibilities (X1), Awards (X2) and Support (X3), simultaneously had a positive and significant effect on employee service effectiveness $(Y)$ of 0.799 or $79.9 \%$ and the remaining $20,1 \%$ is determined by other factors not examined. The variable of responsibility (X1) partially has a positive and significant effect on the effectiveness of employee services $(Y)$ of 0.451 , the variable of appreciation (X2) partially has a positive and significant effect on the effectiveness of employee services $(Y)$ of 0.380 and the variable of support (X3) partial positive and significant effect on the effectiveness of employee services (Y) of 0.323
\end{abstract}

Keywords : Organizational Climate, Effectiveness, Employee Services, Gorontalo City

Abstrak

Pengaruh Iklim Organisasi terhadap Efektivitas Pelayanan Pegawai di Kantor Kota Camat Utara, Kota Gorontalo, Tujuan dari penelitian ini adalah untuk menentukan dan menganalisis Pengaruh Iklim Organisasi terhadap Efektivitas Pelayanan Pegawai. Penelitian ini menggunakan sampel sebanyak 33 responden, kuesioner digunakan sebagai alat pengumpulan data primer dan data dianalisis menggunakan alat analisis jalur. Berdasarkan hasil penelitian ini bahwa iklim organisasi terdiri dari Responsibility (X1), Awards (X2) ) dan Dukungan (X3), secara simultan memiliki pengaruh positif dan signifikan terhadap efektivitas Pelayanan Pegawai $(Y)$ sebesar 0,799 atau $79,9 \%$ dan sisanya $20,1 \%$ ditentukan oleh faktor lain yang tidak diperiksa. Variabel tanggung jawab (X1) secara parsial memiliki pengaruh positif dan signifikan terhadap efektivitas layanan karyawan $(\mathrm{Y})$ sebesar 0,451 , variabel penghargaan $(\mathrm{X} 2)$ secara parsial berpengaruh positif dan signifikan terhadap efektivitas Pelayanan Pegawai $(\mathrm{Y})$ dari 0,380 dan variabel dukungan (X3) parsial berpengaruh positif dan signifikan terhadap efektivitas Pelayanan Pegawai (Y) sebesar 0,323.

Kata Kunci : Iklim Organisasi, Efektivitas, Pelayanan Pegawai, Kota Gorontalo 


\section{Pendahuluan}

Pembangunan pada dasarnya merupakan upaya yang dilakukan oleh pemerintah untuk memperbaiki keterbelakangan dan ketertinggalan dalam semua bidang kehidupan menuju suatu keadaan yang lebih baik dari pada keadaan sebelumnya. Tujuan pembangunan nasional bangsa Indonesia yaitu mewujudkan masyarakat yang adil dan makmur baik material maupun spiritual. Masyarakat adalah pelaku utama pembangunan dan pemerintah berkewajiban untuk mengarahkan, membimbing serta menciptakan suasana yang menunjang. Dengan demikian output dari pelaksanaan tugas adalah berupa jasa pelayanan yang diberikan sehingga pelayanan dikatakan efektif apabila pegawai berhasil dalam melaksanakan tugasnya. Dengan kata lain keberhasilan tugas pegawai dalam pembangunan nasional banyak tergantung pada kerja dan kemampuan pegawai.

Pegawai menempati posisi yang penting dalam pelaksanaan pembangunan karena merupakan salah satu instrumen penting yang akan menopang dan memperlancar usaha-usaha pembangunan. Berhasilnya pembangunan ini memerlukan sistem dan aparatur pelaksana yang mampu tanggap dan kreatif serta pengelolaan yang sesuai dengan prinsip-prinsip manajemen modern dalam sikap perilaku dan kemampuan teknisnya termasuk di dalamnya adalah memberikan pelayanan yang efektif kepada masyarakat yang ada di wilayah kerjanya. Karena pelayanan yang efektif akan memperlancar jalannya proses pembangunan. Dengan alasan itulah penulis mengambil efektivitas pelayanan sebagai variabel yang diteliti. Iklim organisasi dapat diartikan sebagai lingkungan psikologis perusahaan. Adanya ciri yang unik dari perusahaan/organisasi tertentu, bersama dengan kegiatan dan prilaku manajemen, sangat menentukan iklim di suatu lingkungan kerja.

Kantor Camat Kota Utara Kota Gorontalo sebagai institusi pemerintah yang bertugas untuk memberikan pelayanan kepada masyarakat dan bertujuan untuk memperlancar penyaluran dana APBD baik pembayaran gaji pegawai, anggarananggaran pembangunan yang bersumber dari pusat (APBN). Sebagai lembaga pelayan masyarakat maka dituntut harus mampu melaksanakan fungsi utamanya yaitu memberikan pelayanan dengan baik, cekatan, efektif dan efisien. Ada berbagai macam faktor yang dapat mempengaruhi efektivitas pelayanan, seperti yang dikemukakan oleh Moenir bahwa efektivitas pelayanan dari birokrasi pemerintah dapat dipengaruhi oleh kepuasan masyarakat yang dilayani dan juga tingkat kedisiplinan pegawai dengan mentaati peraturan dan prosedur yang ada sehingga tujuan organisasi dapat tercapai. Selain itu, Steers juga mengemukakan bahwa pada dasarnya cara yang terbaik untuk meneliti efektivitas ialah dengan memperhatikan secara serempak tiga buah konsep yang saling berhubungan yaitu optimasi tujuan, perspektif sistematika dan tekanan pada segi perilaku manusia dalam susunan organisasi.

Efektivitas sebagai usaha untuk mencapai suatu keuntungan bahwa efektivitas sebagai usaha untuk mencapai suatu keuntungan maksimal bagi organisasi dengan segala cara. Berkaitan dengan konsep efektivitas, Efektivitas merupakan keadaan yang mengandung pengertian mengenai terjadinya suatu efek atau akibat yang dikehendaki. Kalau seseorang melakukan suatu perbuatan dengan maksud tertentu yang dikehendaki, maka perbuatan itu dikatakan efektif kalau menimbulkan akibat atau mencapai maksud sebagaimana yang dikehendaki. Hasibuan (2002:46), mengatakan 
bahwa efektivitas juga dapat diukur dari motivasi pegawai dalam melaksanakan pekerjaanya. Lain halnya dengan Thoha yang menjelaskan bahwa efektivitas suatu organisasi juga dipengaruhi oleh perilaku-perilaku pegawai yang ada dalam organisasi tersebut. Sedangkan Kotler berpendapat bahwa efektivitas suatu organisasi dapat dipengaruhi oleh iklim kerja, manajemen, pemasaran, lingkungan dan kinerja organisasi tersebut.

Menurut pengamatan penulis, serta wawancara dengan bapak Syamsul Bachri,SE,M.Si selaku Sekertaris Camat mengungkapkan bahwa pelayanan yang diberikan oleh pegawai kantor Camat Kota Utara Kota Gorontalo belum sepenuhnya optimal. Ada beberapa fenomena misalnya: Optimalisasi tujuan belum semuanya terealisasi misalnya target kinerja selama 1 tahun hanya sekitar $80-90 \%$ terelialisasi , keluhan dari masyarakta terkait dengan proses pelayanan Umum, terutama pengurusan serta pengantar pembuatan Kartu Tanda Penduduk (KTP), Akte Jual Beli Tanah, dan legalisir surat-surat dirasakan masih kurang efektif,dalam hal sistematika, pekerjaan belum dihayati sebagai suatu proses yang membutuhkan ketekunan, dan sekaligus saran yang penting dalam mewujudkan tujuan organisasi, ,dalam hal perilaku pegawai, hubungan antara pegawai dalam satu seksi yang masih dirasa kurang akrab,masih pegawai dalam menjalankan tugas seperti datang tidak tepat waktu dan pulang lebih awal menyebabkan pelayanan menjadi lamban. Eksistensi efektifitas pelayanan umum ini diasumsikan diduga karena iklim organisasi pada Kantor camat Kota Utara belum kondusif. Misalnya dalam hal tanggung jawab belum dilaksanakan belum dilaksanakan sesuai dengan tofoksi,kurangnya dukungan dari pegawai dalam mengambil keputusan peraturan organisasi belum dilaksanakan dengan baik

\section{A. Kajian Pustaka}

\section{Pengertian Iklim Organisasi}

Robert Stringer (2012: 101) "menyatakan bahwa iklim organisasi berfokus pada persepsi-persepsi yang masuk akal atau dapat dinilai, terutama yang memunculkan motivasi, sehingga mempunyai pengaruh langsung terhadap kinerja anggota organisasi".

Gibson, Ivancevich dan Donelly (2010 : 702 ) "menyatakan bahwa Iklim organisasi adalah serangkaian keadaan lingkungan yang dirasakan secara langsung atau tidak langsung oleh karyawan. Defenisi ini menggambarkan iklim organisasi sebagai beberapa keadaan atau kondisi dalam satu rangkaian yang secara langsung atau tidak langsung, sadar atau tidak sadar memengaruhi karyawan".

Simamora (2011:31) "menyatakan bahwa iklim organisasi terdiri dari hubungan antar karyawan dan kombinasi antara nilai dan tujuan yang ditetapkan oleh perusahaan". Lebih lanjut simamora mengatakan bahwa bahwa setiap organisasi akan memiliki iklim organisasi yang berbeda. Keanekaragaman pekerjaan yang dirancang di dalam organisasi, atau sifat individu yang ada akan menggambarkan perbedaan tersebut. Semua organisasi tentu memiliki strategi dalam memanajemen SDM. Iklim organisasi yang terbuka memacu karyawan untuk mengutarakan kepentingan dan ketidakpuasan tanpa adanya rasa takut akan tindakan balasan dan perhatian. 
Stinger (Wirawan, 2012:48) mendefinisikan bahwa iklim organisasi sebagai koleksi dan pola lingkungan yang menentukan munculnya motivasi serta berfokus pada persepsi-persepsi yang masuk akal atau dapat dinilai, sehingga mempunyai pengaruh langsung terhadap kinerja anggota organisasi. Tagiuri dan Litwin mengatakan bahwa iklim organisasi merupakan kualitas lingkungan internal organisasi yang secara relatif terus berlangsung, dialami oleh anggota organisasi dan mempengaruhi perilaku mereka serta dapat dilukiskan dalam satu set karateristik atau sifat organisasi.

Menurut Steers, bila kita membahas konsep iklim kerja dalam suatu organisasi, itu berarti kita sedang membicarakan mengenai sifat-sifat atau ciri yang dirasa terdapat dalam lingkungan kerja dan timbul terutama karena kegiatan organisasi, yang dilakukan secara sadar atau tidak dan yang dianggap mempengaruhi perilaku kemudian (Steers, 1985:120).

Davis dan Newstrom (2013:94), iklim organisasi adalah lingkungan manusia di dalam mana para pegawai organisasi melakukan pekerjaan mereka. Sedangkan pendapat yang senada juga diungkapkan oleh Kuncorohadi (1983), iklim organisasi adalah suasana dalam suatu organisasi yang diciptakan oleh para hubungan antar pribadi yang berlaku dalam organisasi tersebut.

Wirawan (2012: 69), mendefenisikan iklim organisasi sebagai persepsi anggota organisasi baik secara individual maupun kelompok dan mereka yang secara tetap berhubungan dengan organisasi misalnya pemasok, konsumen, konsultan dan kontraktor, mengenai apa yang ada atau terjadi di lingkungan internal organisasi secara rutin, yang mempengaruhi sikap dan perilaku organisasi dan kinerja anggota organisasi yang kemudian menentukan kinerja organisasi. Jadi iklim organisasi merupakan harapan-harapan serta cara pandang individu terhadap organisasi. Walaupun pada dasarnya sama, namun masing- masing peneliti mempunyai cara pandang yang berbeda dalam mendefenisikannya.

Dari pendapat-pendapat diatas dapat disimpulkan bahwa iklim organisasi dalam organisasi karakteristik yang dirasakan dalam lingkungan kerja dan timbul karena aktivitas organisasi yang dilakukan secara sadar maupun tidak sadar dan dianggap memengaruhi kelancaran aktivitas organisasi. Apabila iklim yang ada bermanfaat bagi para pegawai maka dapat diharapkan tingkat perilaku ke arah tujuan semakin tinggi dan itu berarti efektivitas organisasi dapat tercapai. Sebaliknya bila iklim yang ada bertentangan dengan tujuan, kebutuhan dan motivasi karyawan maka dapat mengganggu kinerja dan prestasi serta kepuasan karyawan sehingga dapat mengurangi optimalisasi dalam pencapaian tujuan organisasi

\section{Sifat Iklim Organisasi}

Gibson (2013: 127) menyatakan bahwa, ada 4 sifat iklim organisasi, antara lain:

1) Iklim baik secara organisasi

Individu maupun kelompok, secara keseluruhan bersifat psikologis dan persepsi. Individu yaitu persepsi yang diperoleh oleh seluruh anggota dari satuan unit sosial.

2) Semua iklim adalah abstrak. 
Orang-orang biasanya memanfaatkan informasi tentang barang lain dan berbagai kegiatan yang terjadi dalam organisasi tersebut untuk membentuk suatu rangkuman persepsi mengenai iklim. Setelah itu digabungkan hasil dari pengamatan mereka dan pengalaman pribadi orang lain untuk dibuat peta kognitif dari orang tersebut.

3) Iklim bersifat abstrak dan perseptual.

Maka orang-orang memiliki prinsip-prinsip yang sama dengan persepsi seperti konsep psikologis yang lainnya. Ketika prinsip ini digunakan dalam pengamatan lingkungan kerja maka sebuah deskripsi yang bersifat multidimensi akan dihasilkan.

4) Iklim itu sendiri.

Didasari lebih dekriptif daripada evaluatif, jadi peneliti lebih banyak menanyakan apa yang mereka lihat dalam lingkungan kerja mereka pada seseorang dibandingkan menanyakan kepada mereka untuk menyatakan apakah itu baik atau buruk.

\section{Aspek-Aspek Iklim Organisasi}

Faktor-faktor yang membentuk iklim organisasi menurut Steers (1985:125) yaitu struktur organisasi, teknologi organisasi, lingkungan tugas luar atau dari kebijakan dan praktek yang ditetapkan oleh manajemen puncak. Selanjutnya untuk memperjelas dimensi-dimensi iklim organisasi bisa dilihat dalam pendapat Campbell dan Beaty (dalam Steers, 1985) yang mengemukakan 10 dimensi iklim organisasi, yaitu:

1. Struktur tugas

2. Hubungan imbalan hukum

3. Sentralisasi keputusan

4. Tekanan pada prestasi

5. Tekanan pada latihan dan pengembangan

6. Keamanan versus risiko

7. Keterbukaan versus ketertutupan

8. Status dan semangat

9. Pengakuan dan umpan-balik

10. Kompetensi dan keluwesan organisasi secara umum

Batasan pengertian iklim organisasi itu bisa dilihat dalam dimensi iklim organisasi. Steve Kelneer menyebutkan enam dimensi iklim organisasi sebagai berikut :

1. Flexibility conformity. Fleksibilitas dan comfomity merupakan kondisi organisasi yang untuk memberikan keleluasan bertindak bagi karyawan serta melakukan penyesuaian diri terhadap tugas-tugas yang diberikan. Hal ini berkaitan dengan aturan yang ditetapkan organisasi, kebijakan dan prosedur yang ada. Penerimaan terhadap ide-ide yang baru merupakan nilai pendukung di dalam mengembangkan iklim organisasi yang kondusif demi tercapainya tujuan organisasi.

2. Resposibility Hal ini berkaitan dengan perasaan karyawan mengenai elaksanaan tugas organisasi yang diemban dengan rasa tanggung jawab atas hasil yang dicapai, karena mereka terlibat di dalam proses yang sedang berjalan. 
3. Standards. Perasaan karyawan tentang kondisi organisasi dimana manajemen memberikan perhatian kepada pelaksanaan tugas dengan baik, tujuan yang telah ditentukan serta toleransi terhadap kesalahan atau hal-hal yang kurang sesuai atau kurang baik.

4. Reward. Hal ini berkaitan dengan perasaan karyawan tentang penghargaan dan pengakuan atas pekerjaan yang baik.

5. Clarity. Terkait dengan perasaan pegawai bahwa mereka mengetahui apa yang diharapkan dari mereka berkaitan dengan pekerjaan, peranan dan tujuan organisasi.

6. Tema Commitmen. Berkaitan dengan perasaan karyawan mengenai perasaan bangga mereka memiliki organisasi dan kesediaan untuk berusaha lebih saat dibutuhkan.

Stringer (Wirawan, 2012:54), menyebutkan bahwa karakteristik atau dimensi iklim organisasi dapat mempengaruhi anggota organisasi untuk berperilaku tertentu. la juga mengatakan dimensi yang diperlukan, yaitu:

1. Tanggung jawab. yaitu merefleksikan perasaan karyawan bahwa mereka menjadi "pimpinan diri sendiri" dan tidak pernah meminta pendapat mengenai keputusannya dari orang lain. meliputi kemandirian dalam menyelesaikan pekerjaan. Adanya struktur organisasi yang tegas dan tergambar dalam bagan. Adanya pembagian atas tugas/pekerjaan yang jelas dalam organisasi.Terjalinnya komunikasi yang baik antara atasan dan bawahan maupun sesama rekan kerja

2. Penghargaan. yaitu perasaan karyawan diberi imbalan yang layak setelah menyelesaikan pekerjaannya dengan baik. meliputi imbalan atau upah yang terima karyawan setelah menyelesaikan pekerjaan. Penghargaan ini meliputi pemberian imbalan tambahan bagi pegawai yang berprestasi. tingkat penghargaan bagi para pegawai yang berprestasi.rasa aman dan nyaman pada saat bekerja .adanya insentif yang sesuai dengan pekerjaannya.

3. Dukungan. yaitu merefleksikan perasaan karyawan mengenai kepercayaan dan saling mendukung yang berlaku dikelompok kerja. Meliputi yang lain. Partisipasi anggota dalam mengambil keputusan. kebebasan pegawai mengambil tindakan dalam situasi darurat. peraturan organisasi yang dijalankan dengan baik oleh pegawai. semangat pegawai dalam bekerja. kejelasan sistem penilaian kerja aktivitas organisasi yang mempunyai orientasi terhadap pengembangan bagi pegawai

\section{Pelayanan}

Moenir (2010:53) "berpendapat bahwa pelayanan adalah kegiatan yang dilakukan oleh seseorang atau sekelompok orang dengan landasan faktor material melalui sistem, prosedur dan metode tertentu dalam rangka usaha memenuhi kepentingan orang lain sesuai dengan haknya".

Kata pelayanan itu sendiri merupakan terjemahan dari istilah asing, yaitu service. Menurut Reading (1986), pengertian service adalah pekerjaan yang harus dilakukan seorang pelayan pada tuannya. Tampubolon (2001:53) menyatakan bahwa pelayanan adalah orang yang melakukan sesuatu yang baik bagi orang lain karena itu seorang pelayan yang baik ialah "melayani, bukan dilayani". Sebagaimana menurut Joko Widodo (2011:43) pelayanan publik diartikan sebagai pemberian layanan (melayani) 
keperluan orang atau masyarakat yang mempunyai kepentingan pada organisasi itu sesuai dengan aturan pokok dan tata cara yang telah ditetapkan. Dari pengertian di atas terlihat bahwa service atau pelayanan merupakan jasa yang diberikan oleh orang perorangan organisasi swasta maupun instansi pemerintah.

Kotler (Nasution, 2001:61) menjelaskan bahwa jasa (service) adalah aktivitas atau manfaat yang ditawarkan oleh satu pihak kepada pihak lain yang pada dasarnya tidak berwujud dan tidak menghasilkan kepemilikan apapun.

Dari pengertian di atas tersirat bahwa suatu pelayanan pada dasarnya melibatkan dua pihak yang saling berhubungan yaitu organisasi pemberi pelayanan di satu pihak dan masyarakat sebagai penerima pelayanan di pihak lainnya. Jika organisasi mampu memberikan pelayanan yang optimal dan memenuhi tuntutan dari masyarakat, maka dapat dikatakan organisasi tersebut telah mampu memberikan pelayanan yang memuaskan pada masyarakat.

\section{Efektivitas Pelayanan}

Efektif dalam Kamus Besar Bahasa Indonesia berarti dapat membawa hasil, berhasil guna. Sedangkan menurut Handoko (2011) efektivitas adalah kemampuan untuk memilih tujuan yang tepat atau peralatan yang tepat untuk mencapai tujuan yang telah ditetapkan.

Efektivitas adalah suatu keadaan yang mengandung pengertian mengenai terjadinya sesuatu efek atau akibat yang dikehendaki. Kalau seseorang melakukan suatu perbuatan dengan maksud tertentu yang memang dikehendaki, maka orang itu dikatakan efektif kalau menimbulkan akibat sebagaimana yang dikehendakinya (Ensiklopedi Administrasi, 2012:147).

Definisi lain yang dapat dijadikan acuan yaitu bahwa Efektivitas ialah pengukuran dalam arti tercapainya sasaran atau tujuan yang telah ditentukan sebelumnya. Jelaslah bila sasaran atau tujuan untuk mencapai tujuan organisasi sesuai dengan yang direncanakan sebelumnya, hal ini dikatakan efektif. Jadi apabila tujuan atau sasaran tidak sesuai dengan yang telah ditentukan, maka pekerjaan itu dikatakan tidak efektif.

Sondang P. Siagian (2010:151) berpendapat bahwa efektivitas terkait penyelesaian pekerjaan tepat pada waktu yang telah ditetapkan sebelumnya atau dapat dikatakan apakah pelaksanaan sesuatu tercapai sesuai dengan yang direncanakan sebelumnya. M. Manullang (2006) berpendapat : Prestasi atau efektivitas organisasi pada dasarnya adalah efektivitas perorangan, atau dengan kata lain bila tiap anggota organisasi secara terkoordinasi melaksanakan tugas dan pekerjaannya masing-masing dengan baik, efektivitas organisasi secara keseluruhan akan timbul dan sasaran organisasi dapat tercapai sesuai dengan yang diharapkan .

Dari bermacam-macam pendapat di atas dapat disimpulkan atau terlihat bahwa efektivitas lebih menekankan pada aspek tujuan dari suatu organisasi, jadi jika suatu organisasi telah berhasil mencapai tujuan yang telah ditetapkan oleh sebuah organisasi atau perusahaan atau lembaga, maka dapat dikatakan telah mencapai efektivitas dengan 
baik. Dengan demikian efektivitas pada hakekatnya berorientasi pada pencapaian tujuan organisasi yang telah ditentukan sebelumnya.

Moenir (2011:64) mengatakan bahwa pelayanan adalah kunci keberhasilan dalam berbagai usaha atau kegiatan yang bersifat jasa. Jadi dalam memberikan pelayanan kepada masyarakat harus seefektif mungkin. Secara umum pelayanan yang efektif dapat berarti tercapainya tujuan pelayanan yang telah ditetapkan organisasi dan masyarakat merasa puas dengan pelayanan yang didapatnya. Lebih lanjut Sondang (2010:53) mengatakan : Bahwa konsep birokrasi yang rasional sangat mengandalkan pada peraturan-peraturan dan prosedur yang kesemuanya dimaksudkan untuk membantu tercapainya tujuan dan terlaksananya nilai-nilai dan norma-norma yang diinginkan.

Dengan melihat konsep tentang pelayanan yang telah diuraikan di atas, bahwa pelayanan adalah suatu usaha yang dilakukan oleh seseorang atau kelompok orang atau instansi tertentu untuk memberikan bantuan dan kemudahan kepada masyarakat atau kelompok yang dilayani dalam rangka mencapai tujuan tertentu. Maka, dapat dikatakan bahwa efektivitas pelayanan aparat adalah tercapainya suatu tujuan yang dilakukan oleh aparat dalam pelayanan sesuai dengan ketentuan yang telah ditetapkan. Efektivitas lebih menekankan pada aspek tujuan dari suatu organisasi.

\section{Pengukuran Efektivitas Pelayanan}

Untuk mengukur efektivitas pelayanan maka kita dapat melihatnya dari optimasi tujuan, perspektif sistematika dan perilaku pegawai dalam organisasi. Dari konsep tersebut, indikator-indikator efektivitas pelayanan aparat menurut Moenir (2010:56) adalah sebagai berikut :

\section{a. Optimasi tujuan,}

Efektivitas pelayanan dapat diukur dengan indikator optimasi tujuan yaitu bagaimana kita melihat pada pencapaian target kerja, apakah sesuai dengan yang telah direncanakan atau tidak. Kita juga melihat apakah ada keluhan yang datang dari masyarakat tentang pelayanan yang sudah diberikan pegawai atau tidak, sebab adanya keluhan berarti menunjukkan tujuan organisasi belum tercapai sepenuhnya.

\section{b. Perspektif sistematika,}

Indikator lain yang digunakan untuk mengukur efektivitas pelayanan adalah perspektif sistematika yaitu melihat pada kemampuan masing-masing pegawai dalam menyelesaikan pekerjaan sesuai dengan kedudukannya dalam organisasi tersebut, apakah pegawai mampu mengerjakan tugasnya dengan kemampuan sendiri, apakah pegawai memiliki keterampilan atau keahlian khusus.

\section{c. Perilaku pegawai dalam organisasi.}

Indikator ketiga yang digunakan untuk mengukur efektivitas pelayanan adalah perilaku pegawai dalam organisasi, yaitu bagaimana tingkat ketelitian pegawai dalam melaksanakan pekerjaannya, baik ketelitian dalam hal kebersihan maupun tingkat kesalahan yang mungkin terjadi pada saat bekerja. Bagaimana kita melihat pada 
kecepatan dan ketepatan waktu pegawai dalam menyelesaikan pekerjaannya, bagaimana konsentrasi pegawai dalam bekerja.

\section{Hubungan Iklim Organisasi Terhadap Efektivitas Pelayanan.}

Suasana iklim organisasi tempat pegawai bekerja perlu diperhatikan. Iklim kerja dalam suatu organisasi merupakan suatu sifat atau ciri yang dirasakan dalam lingkungan kerja dan timbul karena kegiatan organisasi yang dilakukan secara sadar maupun tidak sadar dan dianggap mempengaruhi kelancaran aktivitas organisasi. Bagaimana cara pegawai berinteraksi dengan masyarakat pada saat melayani, bagaimana hubungan antar pegawai dalam organisasi tersebut, sehingga pelayanannya menjadi efektif. Dalam hal ini yang dimaksud adalah iklim organisasi dalam kantor camat tempat pegawai melayani kepentingan masyarakat. Hal ini sangat penting guna mendukung tercapainya pelayanan yang efektif terhadap masyarakat.

Iklim organisasi yang baik dalam suatu organisasi sangat penting artinya karena efektivitas setiap organisasi sangat ditentukan oleh iklim kerja yang ada dalam organisasi setiap pegawai bekerja, dalam hal ini adalah organisasi kecamatan. Seperti diungkapkan oleh Steers bahwa : "iklim memang merupakan faktor pengaruh yang penting bagi prestasi dan kepuasan kerja." Dari pendapat Steers tersebut kita dapat melihat bahwasannya iklim kerja sangat berpengaruh pada prestasi dan kepuasan kerja pegawai yang dalam penelitian ini adalah tercapainya efektivitas pelayanan aparat kecamatan.

Dari indikator-indikator iklim organisasi yang sudah diterangkan dalam konsep iklim organisasi diatas, kita dapat menyimpulkan bahwa kemampuan pegawai, struktur tugas yang jelas, adanya pelatihan, kesejahteraan dan rasa aman yang semakin meningkat akan sangat mendukung kelancaran kerja dan secara otomatis meningkatkan efektivitas pelayanan pemerintah kecamatan. Selain itu juga sarana penunjang kerja yang semakin memadai akan memperlancar kerja dan tugas-tugas yang pada akhirnya akan meningkatkan efektivitas pelayanan.

Dari uraian tersebut terlihat bahwa iklim organisasi yang baik dalam organisasi sangat penting dalam rangka mewujudkan efektivitas pelayanan suatu organisasi, dalam hal ini pencapaian efektivitas pelayanan kecamatan. Apabila iklim yang ada bermanfaat bagi para pegawai maka dapat diharapkan tingkat perilaku ke arah tujuan semakin tinggi dan itu berarti efektivitas pelayanan dapat tercapai.

\section{B. Kerangka Pemikiran}

Suatu organisasi dalam pencapaian tujuannya akan berhasil melalui usaha yang sungguh-sungguh. Oleh karena itu efektivitas yang tinggi dicapai organisasi tidak diperoleh secara kebetulan. Dari sikap inilah, aparat akan taat serta patuh terhadap aturan yang ada sehingga pencapaian sasaran organisasi dapat diperoleh secara optimal.

Iklim organisasi penting untuk diciptakan karena merupakan persepsi seseorang tentang apa yang diberikan oleh organisasi dan dijadikan dasar bagi penentuan tingkah laku anggota selanjutnya. Iklim ditentukan oleh seberapa baik anggota diarahkan, dibangun dan dihargai oleh organisasi

Konsep iklim dalam suatu organisasi, itu berarti kita sedang membicarakan mengenai sifat-sifat atau ciri yang dirasa terdapat dalam lingkungan kerja dan timbul terutama karena kegiatan organisasi, yang dilakukan secara sadar atau tidak dan yang dianggap mempengaruhi perilaku kemudian. Menurut Steers ada beberapa hal yang perlu diperhatikan berhubungan dengan definisi iklim kerja organisasi, yaitu : Pertama, iklim 
organisasi tertentu adalah iklim yang dilihat oleh para pekerjanya, jadi tidak selalu iklim yang "sebenarnya". Kedua, iklim organisasi adalah anggapan adanya hubungan antara ciri dan kegiatan lainnya dari organisasi dan iklim.

Dari uraian tersebut terlihat arti penting dari iklim organisasi bagi pencapaian efektivitas pelayanan. Oleh karena itu aparat pemerintah kecamatan dituntut harus punya etos kerja yang baik agar tugas-tugas pemerintah yang menjadi kewajibannya dapat terselesaikan dengan baik. Karena tugas yang diemban oleh aparat kecamatan bersifat kompleks, maka camat beserta perangkatnya harus punya disiplin tinggi sehingga dapat memberikan pelayanan yang efektif atau berdaya guna bagi masyarakat. Etos kerja yang baik juga berarti terlaksananya tugas-tugas yang harus dilakukan oleh aparat kecamatan sesuai dengan tujuan yang telah ditetapkan secara bersama-sama. Iklim organisasi dalam penelitian ini hanya digunakan tiga dimensi dari enam dimensi yaitu : tanggung jawab, penghargaan dan dukungan dengan pertimbangan bahwa peneliti memiliki keterbatasan dalam meneliti semua dimensi yang ada Untuk lebih jelasnya dapat dilihat pada gambar berikut :

\section{Hipotesis}

Berdasarkan permasalahan yang telah diuraikan sebelumnya, maka hipotesis penelitian ini adalah bahwa :

1. Iklim organisasi yang terdiri dari tanggung jawab (X1), penghargaan (X2), dan dukungan (X3) secara simultan berpengaruh positif dan signifikan terhadap efektivitas pelayanan pada Kantor Kota Itara Kota Gorontalo

2. Iklim organisasi yang terdiri dari tanggung jawab (X1), secara parsial berpengaruh positif dan signifikan terhadap efektivitas pelayanan pada Kantor Kota Itara Kota Gorontalo

3. Iklim organisasi yang terdiri dari penghargaan (X2), secara parsial berpengaruh positif dan signifikan terhadap efektivitas pelayanan pada Kantor Kota Itara Kota Gorontalo

4. Iklim organisasi yang terdiri dari dukungan (X3) secara parsial berpengaruh terhadap efektivitas pelayanan pada Kantor Kota Itara Kota Gorontalo

\section{Metode Penelitian}

Metode yang digunakan dalam penelitian ini adalah metode kuantitatif yang menggambarkan adanya pengaruh antara iklim organisasi $(X)$ dan efektivitas pelayanan (Y). Adapun jenis penelitian yang digunakan peneliti adalah Penelitian Survai

\section{A. Definisi Operasionalisasi Variabel penelitian.}

Dalam peneliitian ini, peneliti menetapkan iklim organisasi sebagai variabel bebas atau independen (Variabel $\mathrm{X}$ ) dan efektivitas pelayanan sebagai variabel terikat atau dependen (variabel $\mathrm{Y}$ ). Untuk menghindari kesalahan dalam menafsirkan variabel-variabel dalam penelitian ini, maka perlu dijelaskan devinisi operaional masing-masing variabel dalam penelitian ini sebagai berikut:

Efektivitas Pelayanan (Y). Yaitu tercapainya suatu tujuan yang dilakukan oleh pegawai dalam pelayanan sesuai dengan ketentuan yang telah ditetapkan.

Iklim Organisasi (X). Yaitu sifat-sifat atau ciri-ciri yang dirasakan dalam lingkungan kerja dan timbul karena kegiatan organisasi yang dilakukan secara sadar maupun tidak sadar dan dianggap mempengaruhi kelancaran aktivitas organisasi. 
Tanggung Jawab (X1) : Merefleksikan perasaan karyawan bahwa mereka adalah "bos bagi diri sendiri"yang. Persepsi tanggung jawab tinggi menunjukkan anggotanya merasa didorong untuk memecahkan problemnya sendiri. Tanggung jawab rendah menunjukkan bahwa pengambilan keputusan terhadap pendekatan baru tidak diharapkan

Penghargaan (X2) : Perasaan karyawan diberi imbalan yang layak setelah menyelesaikan pekerjaannya dengan baik. Meliputi imbalan atau upah yang terima karyawan setelah menyelesaikan pekerjaan. Mengindikasikan bahwa anggota organisasi merasa dihargai jika mereka dapat menyelesaikan tugas secara baik.

Dukungan (X3)Merefleksikan perasaan karyawan mengenai kepercayaan dan saling mendukung yang berlaku dikelompok kerja. Meliputi hubungan dengan rekan kerja yang lain.

Pernyataan diukur dengan menggunakan skala likert, yang dipakai sebagai kuesioner dengan menggunakan 5 (lima) pilihan. Setiap pilihan akan diberikan bobot nilai yang berbeda seperti tampak dalam tabel berikut :

\section{B. Sumber Data dan Teknik Pengumpulan data}

Dalam penelitian ini sumber data yang digunakan adalah sebagai berikut:

Sumber Data.Dalam penelitian ini data yang dikumpulkan ada dua macam, yaitu :

a. Data Primer : Data ini bersumber dari responden secara langsung. Dalam prakteknya diperoleh dari wawancara dan jawaban responden pada kuesioner yang telah diberikan. Selain itu dari pengamatan langsung terhadap situasi lokasi penelitian.

b. Data Sekunder: Data sekunder diperoleh dari dokumen-dokumen data statistik, buku-buku, majalah, koran dan keterangan lainnya yang ada kaitannya dengan obyek penelitian yang penulis lakukan pada Kantor Camat Kota Utara Kota Gorontalo, misalnya srtuktur organisasi dan visi misi organisaasi

\section{Teknik Pengumpulan Data}

Arikunto (2002) teknik pengumpulan data adalah cara memperoleh data yang diharapkan untuk memperoleh data yang diinginkan, maka penulis menggunakan beberapa teknik sebagai berikut:

1. Observasi : Suatu studi yang disengaja dan sistematis tentang fenomena sosial dan gejala psikis dengan jalan pengamatan dan pencatatan. Metode ini digunakan untuk mengamati keadaan responden yang tidak secara mudah dapat ditangkap melalui metode wawancara dan kuesioner.

2. Wawancara : Suatu percakapan yang diarahkan pada suatu masalah tertentu. Hal ini merupakan proses tanya jawab lisan dimana dua orang atau lebih berhadapan secara fisik. Wawancara ini akan dilakukan pada pegawai Kantor Camat Kota Utara yang lebih mengetahui tentang keadaan sehari-hari. 
3. Kuesioner : Suatu penelitian mengenai suatu masalah yang dilakukan dengan jalan mengedarkan suatu pertanyaan berupa formulir, diajukan secara tertulis kepada responden untuk mendapatkan jawaban tertulis.

\section{Prosedur Penelitian}

Untuk mendapatkan data yang baik dalam arti mendekati secara obyektif harus diperlukan suatu instrument. dengan menggunakan alat ukur yang valid dan andal (reliable). Untuk meyakinkan bahwa instrument yang baik dan andal maka harus diuji validitas dan reabilitasnya sehingga bila digunakan menghasilkan data yang akurat dan obyek.

\section{Uji Validitas}

Validitas menurut Sugiyono (Suharti Ningsih, 2017) menunjukan derajat ketepatanantara data yang sesungguhnya terjadi pada objek dengan data yang dikumpulkan oleh peneliti untuk mencari validitas sebuah item, kita mengkorelasikan skor item dengan total item-item tersebut. Jika koefisien antara item dengan total item sama atau diatas 0,3 maka item tersebut dinyatakan valid, tetapi jika nilai korelasinya dibawah 0,3 maka item terebut dinyatakan tidak valid Untuk mencari nilai koefisien, maka peneliti menggunakan rumus pearson product moment sebagai berikut :

Dimana:

$$
r X Y=\frac{n\left(\sum X Y\right)-\left(\sum X\right) \cdot\left(\sum \mathrm{Y}\right)}{\sqrt{\left\{\mathrm{n} \cdot \sum \mathrm{X}^{2}\right\}} \cdot\left\{\mathrm{n} \cdot \sum \mathrm{Y}^{2}-\left(\sum \mathrm{Y}\right)^{2}\right.}
$$

$$
\begin{aligned}
& r \quad=\text { Angka korelasi } \\
& X \quad=\text { Skor pertanyaan }(k e-n) \text { variabel } X \\
& Y=\text { Skor pertanyaan }(\text { ke- } n \text { ) variabel } Y \\
& n \quad=\text { Jumlah responden } \\
& X Y=\text { Skor pertanyaan dikali total pertanyaan }
\end{aligned}
$$

Syarat minimum untuk dianggap suatu butir instrument valid adalah nilai indeks valid adalah nilai indeks validitasnya $\geq 0,3$ Sugiyono,(Suharti Ningsih, 2017). Oleh karena itu, semua pernyataan yang memiliki tingkat korelasi dibawah 0,3 harus diperbaiki karena dianggap tidak valid.

\section{Uji Reliabilitas}

Uji reliabilitas menurut Sugiyono (Suharti Ningsih, 2017) dilakukan untuk mengetahui seberapa jauh hasil pengukuran tetap konsisten apabila dilakukan pengukuran dua kali atau lebih terhadap gejala yang sama dengan menggunakan alat pengukur sama. Uji reliabilitas dilakukan untuk mengetahui apakah alat ukur yang dirancang dalam bentuk kuesioner dapat diandalkan, suatu alat ukur dapat diandalkan jika alat ukur tersebut digunakan berulangkali akan memberikan hasil yang relatif sama (tidak berbeda jauh). Untuk melihat andal tidaknya suatu alat ukur digunakan pendekatan secara statistika, yaitu melalui koefisien reliabilitas dan apabila koefisien. reliabilitasnya lebih besar dari 0.60 maka secara keseluruhan pernyataan tersebut dinyatakan andal (reliabel).

Uji reliabilitas dalam penelitian ini penulis menggunakan metode Alpha Cronbach 
Keterangan :

$$
a=\left(\frac{k}{k-1}\right)\left(1 \frac{\sum s i}{s t}\right)
$$

$\mathrm{K}=$ Jumlah instrument pertanyaan

$\sum \mathrm{Si}^{2}=$ Jumlah varians dalam setiap instrumen

$\mathrm{S}=$ Varians keseluruhan instrument

\section{Metode Analisis}

Metode Analisis dimaksudkan dalam penelitian ini adalah untuk mengukur besarnya iklim organisasi yang meliputi tanggung jawab (X1), penghargaan (X2) dan dukungan (X3) yang memengaruhi tingkat efektivitas pelayanan pada Kantor Camat Kota Urata Kota Gorontalo

Untuk memastikan sub-sub variabel apakah ada pengaruh iklim organisasi (X) terhadap efektivitas pelayanan ( $\mathrm{Y}$ ), maka pengujian dilakukan dengan uji analis jalur, dengan terlebih dahulu mengkorversi data ordinal ke skala interval serta analisa jalur dapat dilihat gambar berikut ini :

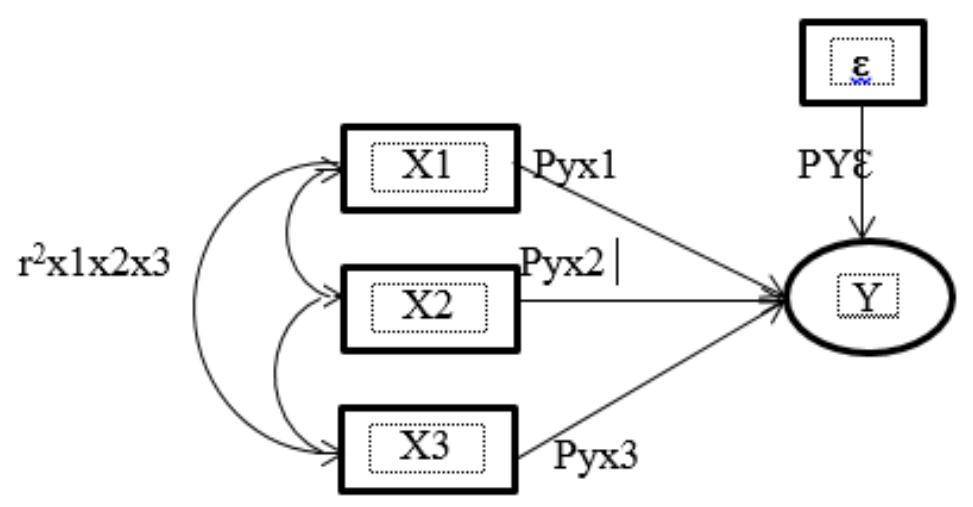

Gambar 1. Struktur Analisis Path

Sumber : Diolah dari data penelitian

Keterangan :

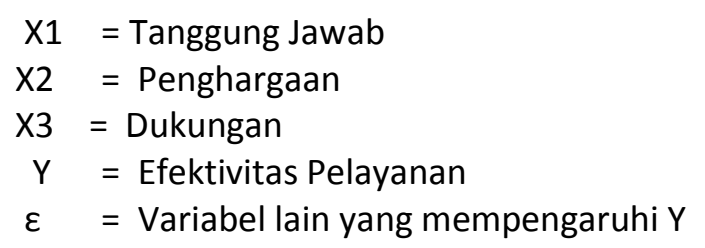

\section{HASIL PENELITIAN DAN PEMBAHASAN}

\section{A. Gambaran Umum Lokasi Penelitian}

Sebelum masa penjajahan Belanda keadaan daerah Gorontalo berbentuk kerajaan-kerajaan yang diatur menurut hukum adat ketatanegaraan Gorontalo. Kerajaan-kerajaan itu tergabung dalam suatu ikatan kekeluargaan yang disebut 
"Pohalaa". Raja dari pohalaa-pohalaa tersebut ditentukan oleh Baate-Baate (pemangku adat).yang menonjol dari kelima pohalaa tersebut adalah pohalaa Gorontalo dan pohalaa Limboto yang merupakan dua kerajaan terbesar. Rakyatnya terbagi dalam suku-suku (linula-linula, yang kemudian disebut kaum) dan dikepalai oleh seorang Olongia.

Jadi asal-usul nama Gorontalo (arti katanya) tidak diketahui lagi, namun jelas bahwa kata "Hulontalo" hingga sekarang masih hidup dalam ucapan orang Gorontalo dan oleh orang Belanda karena kesulitan dalam mengucapkannya, diucapkan dengan "HORONTALO" dan bila dituliskan menjadi "GORONTALO". Pada tahun 1824 daerah Limo Lo Pohalaa telah berada dikekuasaan seorang Asisten Residen disamping pemerintahan tradisional. Pada tahun 1889 sistem pemerintahan kerajaan dialihkan ke pemerintahan langsung yang dikenal dengan istilah "Rechtatreeks Bestur". Wilayah hukum Kotapraja Gorontalo dibagi 3 kecamatan berdasarkan UU No. 29/1959 tersebut dan melalui Keputusan Kepala Daerah Sulawesi Utara No. 102 tanggal 4 Maret 1960 ditetapkan 39 kampung yang masih termasuk dalam wilayah Kotapraja Gorontalo yang terbagi atas 3 kecamatan yaitu Kecamatan Kota Selatan, Kecamatan Kota Barat dan Kecamatan Kota Utara.

Sebutan Kotapraja sesuai dengan istilah yang digunakan dalam UU No. 18/1965 tentang Pemerintahan Daerah yang diganti dengan UU No. 5/1974 tentang Pokok-Pokok Pemerintahan Daerah yang menggantikan istilah Kotapraja menjadi Kotamadya dan saat ini disebut Kota. Sejak tahun 2005 berdasarkan Peraturan Daerah nomor 3 tahun 2005, Kecamatan Kota Utara yang sebelumnya terdiri dari 14 Kelurahan dimekarkan menjadi 2 Kecamatan dengan wilayah pemekarannya adalah Kecamatan Kota Tengah sehingga Kecamatan Kota Utara Kota Gorontalo tinggal memiliki 9 Kelurahan.

Visi : Sejahtera, Maju, Aktif, Religius, Terampil

Misi : Reformasi birokrasi yang berorientasi pada peningkatan tata kelola kapasitas organisasi pemerintah, dan kualitas sumber daya aparatu

\section{B. Analisis Karakteristik Responden}

Dari 33 responden pada penelitian ini dapat dikemukakan identitas responden yang meliputi : Jenis Kelamin dan tingkat pendidikan,

Dari hasil penelitian yang telah dilakukan didapatkan jumlah jenis kelamin responden yang dapat dilihat pada tabel berikut :

Tabel 1. Distribusi Responden Berdasarkan Jenis Kelamin

\begin{tabular}{|c|c|c|}
\hline Jenis Kelamin & Jumlah (Orang) & Presentasi (\%) \\
\hline Laki-laki & 11 & 33,3 \\
\hline Perempuan & 22 & 69,7 \\
\hline Total & 33 & 100 \\
\hline
\end{tabular}

Sumber : Data Primer, diolah 
Dari tabel diatas dapat ditunjukkan bahwa jumlah responden laki-laki yaitu 11 orang atau sekitar $33,3 \%$, sedangkan jumlah responden perempuan sebanyak 22 orang atau $69,7 \%$. Hal ini menunjukkan responden perempuan lebih dominan dari pada responden laki - laki

Tabel 2. Distribusi Responden menurut Tingkat pendidikan

\begin{tabular}{|c|c|c|}
\hline Jenis Kelamin & Jumlah (Orang) & Presentasi (\%) \\
\hline SMU. & 9 & 27,3 \\
\hline Sarjana & 21 & 63,6 \\
\hline Magister & 3 & 9,1 \\
\hline Total & 33 & 100 \\
\hline
\end{tabular}

Sumber : Data Primer, diolah

Jenjang pendidikan dari 33 responden, diketahui bahwa responden dengan tingkat pendidikan SMU. sebesar 9 orang atau sekitar 27,3\% kemudian disusul oleh responden dengan tingkat pendidikan Sarjana sebanyak 21 orang atau 63,6\%.

Dan Tingkat pendidikan Magister sebanyak 3 orang atau sekitar 9,1\%

\section{Hasil Uji validitas dan Reliabilitas}

Pengujian instrumen penelitian ini baik dari segi validitasnya maupun reliabilitasnya terhadap 33 responden diperoleh bahwa hasil instrumen penelitian yang dipergunakan adalah valid dimana nilai $r$ hitung $>0,3$.

a. Uji validitas dan reliabilitas variabel

Tabel 3. Hasil Uji Validitas dan Reliabilitas Variabel Tanggung Jawab (X1)

\begin{tabular}{|l|l|c|c|c|c|}
\hline Variabel & \multirow{2}{*}{$\begin{array}{l}\text { No } \\
\text { Item }\end{array}$} & \multicolumn{2}{|c|}{ Validitas } & \multicolumn{2}{|c|}{ Reliabilitas } \\
\cline { 2 - 4 } & $\begin{array}{c}\text { Koef. Korelasi } \\
\text { (r hitung) }\end{array}$ & Ket & Koef Alpha & Ket \\
\hline \multirow{3}{*}{ X1 } & 1 & 0,317 & Valid & \multirow{2}{*}{$0,756>0,60$} & Reliabel \\
\cline { 2 - 4 } & 2 & 0,430 & Valid & , & \\
\cline { 2 - 4 } & 3 & 0,378 & Valid & , \\
\hline
\end{tabular}

Sumber : Hasil olahan data, 2019

Tabel di atas menjelaskan bahwa semua item pertanyaan untuk variabe tanggung jawab (X1) semua instrumen menunjukkan hasil yang valid dan reliabel. Keputusan ini diambil karena nilai $r$ hitung $>0,3$ Sedangkan koefisien alphanya sebesar $0,756>0,60$. Dengan demikian berarti semua item pertanyaan untuk variabel tanggung jawab adalah valid dan reliabel

a. Uji validitas dan reliabilitas variabel Penghargaan 
Tabel 4. Hasil Uji Validitas dan Reliabilitas Variabel Penghargaan (X2)

\begin{tabular}{|c|c|c|c|c|c|}
\hline \multirow[t]{2}{*}{ Variabel } & \multirow{2}{*}{$\begin{array}{l}\text { No } \\
\text { Item }\end{array}$} & \multicolumn{2}{|c|}{ Validitas } & \multicolumn{2}{|c|}{ Reliabilitas } \\
\hline & & $\begin{array}{l}\text { Koef. korelasi } \\
\text { (r hitung) }\end{array}$ & Ket & Koef Alpha & Ket \\
\hline \multirow{4}{*}{$x 2$} & 1 & 0,420 & Valid & \multirow{4}{*}{$0,758>0,60$} & \multirow{4}{*}{ Reliabel } \\
\hline & 2 & 0,452 & Valid & & \\
\hline & 3 & 0,496 & Valid & & \\
\hline & 4 & 0,510 & Valid & & \\
\hline
\end{tabular}

Sumber : Hasil olahan data, 2019

Tabel di atas menjelaskan bahwa semua item pertanyaan untuk variabel penghargaan (X2) semua instrumen menunjukkan hasil yang valid dan reliabel. Keputusan ini diambil karena nilai nilai $r$ hitung $>0,3$ Sedangkan koefisien alphanya sebesar 0,758 $>0,60$ Dengan demikian berarti semua item pertanyaan untuk variabel penghargaan (X2) adalah valid dan reliabel.

\section{Uji validitas dan reliabilitas variabel Dukungan}

Tabel 5. Hasil Uji Validitas dan Reliabilitas Variabel (X3)

\begin{tabular}{|c|c|c|c|c|c|}
\hline Variabel & $\begin{array}{c}\text { No } \\
\text { Item }\end{array}$ & $\begin{array}{c}|c| \\
\text { Koef. korelasi } \\
\text { ( } \mathrm{r} \text { hitung) }\end{array}$ & Ket & \multirow{2}{*}{ Koef Alpha } & Ket \\
\hline \multirow{4}{*}{ X3 } & 1 & 0,489 & Valid & & \\
\cline { 2 - 4 } & 2 & 0,540 & Valid & \multirow{3}{*}{$0,735>0,60, \quad$ Reliabel } \\
\cline { 2 - 4 } & 3 & 0,629 & Valid & & \\
\cline { 2 - 4 } & 4 & 0,380 & Valid & & \\
\cline { 2 - 4 } & 5 & 0,318 & Valid & & \\
\cline { 2 - 4 } & 6 & 0,530 & Valid & & \\
\hline
\end{tabular}

Sumber : Hasil olahan data, 2019

Tabel di atas menjelaskan bahwa semua item pertanyaan untuk variabel dukungan (X3) semua instrumen menunjukkan hasil yang valid dan reliabel. Keputusan ini diambil karena nilai nilai $r$ hitung $>0,3$ Sedangkan koefisien alphanya sebesar 0,735 >0,60 Dengan demikian berarti semua item pertanyaan untuk variabel dukungan (X3) adalah valid dan reliabel.

Validitas dan Reliabilitas Variabel Efektivitas Pelayanan (Y) 
Tabel 6. Uji Validitas dan Reliabilitas Variabel Efektivitas Pelayanan (Y)

\begin{tabular}{|c|c|c|c|c|c|}
\hline \multirow{2}{*}{$\begin{array}{c}\text { Variab } \\
\text { el }\end{array}$} & \multirow{2}{*}{$\begin{array}{l}\text { No } \\
\text { Item }\end{array}$} & \multicolumn{2}{|c|}{ Validitas } & \multicolumn{2}{|c|}{ Reliabilitas } \\
\hline & & $\begin{array}{c}\text { Koef.Korelasi } \\
\text { (r hitung) }\end{array}$ & Ket & Koef Alpha & Ket \\
\hline \multirow{9}{*}{$Y$} & 1 & 0,427 & Valid & \multirow{9}{*}{$0,875>0,60}$, & \multirow{9}{*}{ Reliabel } \\
\hline & 2 & 0,701 & Valid & & \\
\hline & 3 & 0,343 & Valid & & \\
\hline & 4 & 0,518 & Valid & & \\
\hline & 5 & 0,380 & Valid & & \\
\hline & 6 & 0,518 & Valid & & \\
\hline & 7 & 0,511 & Valid & & \\
\hline & 8 & 0,427 & Valid & & \\
\hline & 9 & 0,619 & Valid & & \\
\hline
\end{tabular}

Sumber : Hasil olahan data, 2019

Tabel di atas menjelaskan bahwa semua item pertanyaan untuk variabel efektivitas pelayanan semua instrumen menunjukkan hasil yang valid dan reliabel. Keputusan ini diambil karena nilai nilai $r$ hitung $>0,3$ Sedangkan koefisien alphanya sebesar 0,875 >0,60. Dengan demikian berarti semua item pertanyaan untuk variabel efektivitas pelayanan adalah valid dan reliabel.

\section{Analisis Variabel Penelitian}

Berdasarkan data yang terkumpul dari 33 responden yang ditetapkan sebagai sampel data masing - masing variabel dapat ditabulasi seperti pada tabel berikut :

\section{Variabel Tanggung jawab (X1)}

Berdasarkan jawaban responden, tentang variabel tanggung jawab dapat dilihat pada Tabel berikut :

Tabel 7. Tanggapan Responden Tentang Variabel Tanggung jawab (X1)

\begin{tabular}{|c|c|c|c|c|c|c|c|c|c|c|}
\hline \multirow{2}{*}{ No } & Bobot & \multicolumn{10}{|c|}{ Variabel Tanggung jawab } \\
\cline { 3 - 12 } & & \multicolumn{3}{|c|}{ Item 1 } & \multicolumn{3}{|c|}{ Item 2 } & \multicolumn{3}{c|}{ Item 3 } \\
\cline { 2 - 12 } & $\mathrm{F}$ & Skor & $\%$ & $\mathrm{~F}$ & Skor & $\%$ & $\mathrm{~F}$ & Skor & $\%$ \\
\hline 1 & 5 & 10 & 50 & 30 & 7 & 35 & 21 & 5 & 25 & 15 \\
\hline 2 & 4 & 19 & 76 & 58 & 23 & 92 & 69 & 26 & 104 & 79 \\
\hline 3 & 3 & 4 & 12 & 12 & 3 & 9 & 10 & 1 & 3 & 3 \\
\hline 4 & 2 & 0 & 0 & 0 & 0 & 0 & 0 & 1 & 2 & 3 \\
\hline 5 & 1 & 0 & 0 & 0 & 0 & 0 & 0 & 0 & 0 & 0 \\
\hline \multicolumn{2}{|c|}{ Jumlah } & 33 & 138 & 100 & 33 & 136 & 100 & 33 & \multirow{2}{*}{134} & 100 \\
\hline
\end{tabular}

Sumber : Data diolah, 2019

Berdasarkan tabel di atas data item (no.1) yang diperoleh dari 33 responden, mendapat skor item 1 sebesar 138 tergolong tinggi. Data item (no.2) mendapat skor yaitu 136, tergolong tinggi. Data item (no.3) mendapat skor 134 tergolong tinggi. Hal ini menunjukkan bahwa pimpinan selalu memberikan tanggung jawab kepada para pegawai dalam rangka peningkatan efektivitas pelayanan pegawai 


\section{Penghargaan (X2)}

Berdasarkan jawaban responden penelitian tentang penghargaan dapat dilihat pada tabel berikut:

Tabel 8. Tanggapan Responden Tentang Variabel Penghargaan

\begin{tabular}{|c|c|c|c|c|c|c|c|c|c|c|c|c|c|}
\hline \multirow[t]{3}{*}{ No } & \multirow{3}{*}{$\begin{array}{l}\text { Bobo } \\
t\end{array}$} & \multicolumn{12}{|c|}{ Variabel penghargaan (X2) } \\
\hline & & \multicolumn{3}{|c|}{ Item 1} & \multicolumn{3}{|c|}{ Item 2} & \multicolumn{3}{|c|}{ Item 3} & \multicolumn{3}{|c|}{ Item 4} \\
\hline & & $\mathrm{F}$ & Skor & $\%$ & $\mathrm{~F}$ & Skor & $\%$ & $\mathrm{~F}$ & Skor & $\%$ & $\mathrm{~F}$ & Skor & $\%$ \\
\hline 1 & 5 & 7 & 35 & 22 & 3 & 15 & 10 & 5 & 25 & 15 & 3 & 15 & 10 \\
\hline 2 & 4 & 20 & 80 & 60 & 19 & 76 & 57 & 21 & 84 & 64 & 21 & 84 & 63 \\
\hline 3 & 3 & 6 & 18 & 18 & 10 & 30 & 30 & 6 & 18 & 18 & 9 & 27 & 27 \\
\hline 4 & 2 & 0 & 0 & 0 & 1 & 2 & 3 & 1 & 2 & 3 & 0 & 0 & 0 \\
\hline 5 & 1 & 0 & 0 & 0 & 0 & 0 & 0 & 0 & 0 & 0 & 0 & 0 & 0 \\
\hline \multicolumn{2}{|c|}{ Jumlah } & 33 & 133 & 100 & 33 & 123 & 100 & 33 & 129 & 100 & 33 & 126 & 100 \\
\hline
\end{tabular}

Sumber : Data diolah, 2019

Berdasarkan tabel di atas data item (no.1) yang diperoleh dari 33 responden, mendapat skor 133, dengan kategori tinggi. Data item (no.2) mendapat skor 123, kategori tinggi. Data item (no.3) mendapat skor 129 kategori tinggi. Data item (no.4) mendapat skor 126 kategori tinggi. Hal ini menunjukkan bahwa pimpinan selalu memperhatikan peningkatan efektivitas kerja pegawai melalui pemberian penghargaan

\section{Variabel Dukungan (X3)} berikut :

Berdasarkan jawaban responden, tentang dukungan dapat dilihat pada Tabel

Tabel 9. Tanggapan Responden Tentang Variabel dukungan (X3)

\begin{tabular}{|c|c|c|c|c|c|c|c|c|c|c|}
\hline \multirow[t]{3}{*}{ No } & \multirow[t]{3}{*}{ Bobot } & \multicolumn{9}{|c|}{ Variabel Dukungan } \\
\hline & & \multicolumn{3}{|c|}{ Item 1} & \multicolumn{3}{|c|}{ Item 2} & \multicolumn{3}{|c|}{ Item 3} \\
\hline & & $\mathrm{F}$ & Skor & $\%$ & $\mathrm{~F}$ & Skor & $\%$ & $\mathrm{~F}$ & Skor & $\%$ \\
\hline 1 & 5 & 5 & 25 & 15 & 3 & 15 & 10 & 10 & 50 & 30 \\
\hline 2 & 4 & 21 & 84 & 64 & 21 & 84 & 63 & 20 & 80 & 60 \\
\hline 3 & 3 & 6 & 18 & 18 & 9 & 27 & 27 & 3 & 9 & 10 \\
\hline 4 & 2 & 1 & 2 & 3 & 0 & 0 & 0 & 0 & 0 & 0 \\
\hline 5 & 1 & 0 & 0 & 0 & 0 & 0 & 0 & 0 & 0 & 0 \\
\hline \multicolumn{2}{|c|}{ Jumlah } & 33 & 129 & 100 & 33 & 126 & 100 & 33 & 139 & 100 \\
\hline \multirow[t]{3}{*}{ No } & \multirow[t]{3}{*}{ Bobot } & \multicolumn{9}{|c|}{ Variabel Dukungan } \\
\hline & & \multicolumn{3}{|c|}{ Item 1} & \multicolumn{3}{|c|}{ Item 2} & \multicolumn{3}{|c|}{ Item 3} \\
\hline & & $\mathrm{F}$ & Skor & $\%$ & $\mathrm{~F}$ & Skor & $\%$ & $\mathrm{~F}$ & Skor & $\%$ \\
\hline 1 & 5 & 7 & 35 & 21 & 6 & 30 & 19 & 7 & 35 & 21 \\
\hline 2 & 4 & 23 & 92 & 69 & 25 & 100 & 75 & 19 & 76 & 58 \\
\hline 3 & 3 & 3 & 9 & 10 & 1 & 3 & 3 & 7 & 21 & 21 \\
\hline 4 & 2 & 0 & 0 & 0 & 1 & 2 & 3 & 0 & 0 & 0 \\
\hline 5 & 1 & 0 & 0 & 0 & 0 & 0 & 0 & 0 & 0 & 0 \\
\hline \multicolumn{2}{|c|}{ Jumlah } & 33 & 136 & 100 & 33 & 135 & 100 & 33 & 132 & 100 \\
\hline
\end{tabular}

Sumber : Data diolah, 2019 
Berdasarkan tabel di atas data item (no.1) yang diperoleh dari 33 responden, mendapat skor item sebesar 129 tergolong tinggi. Data item (no.2) mendapat skor yaitu 126 , tergolong tinggi. Data item (no.3) mendapat skor 139 tergolong tinggi. Data item (no.4) mendapat skor 136 tergolong tinggi Data item (no.5) mendapat skor 135 tergolong tinggi Data item (no.6) mendapat skor 132 tergolong tinggi Hal ini menunjukkan bahwa pimpinan selalu memberikan dukungan kepada para pegawai dalam rangka peningkatan efektivitas pelayanan pegawai

\section{Efektivitas pelayanan $(\mathrm{Y})$}

Berdasarkan hasil jawaban dari 33 orang responden tentang efektivitas pelayanan kerja pegawai dapat dilihat pada tabel berikut :

Tabel 10. Tanggapan Responden Tentang Variabel Efektivitas pelayanan ( $Y$ )

\begin{tabular}{|c|c|c|c|c|c|c|c|c|c|c|}
\hline \multirow[t]{3}{*}{ No } & \multirow[t]{3}{*}{ Bobot } & \multicolumn{9}{|c|}{ Variabel efektivitas pelayanan } \\
\hline & & \multicolumn{3}{|c|}{ Item 1} & \multicolumn{3}{|c|}{ Item 2} & \multicolumn{3}{|c|}{ Item 3} \\
\hline & & $\mathrm{F}$ & Skor & $\%$ & $\mathrm{~F}$ & Skor & $\%$ & $\mathrm{~F}$ & Skor & $\%$ \\
\hline 1 & 5 & 9 & 45 & 27 & 4 & 20 & 12 & 2 & 10 & 7 \\
\hline 2 & 4 & 21 & 84 & 63 & 27 & 108 & 81 & 26 & 104 & 78 \\
\hline 3 & 3 & 3 & 9 & 10 & 2 & 6 & 7 & 5 & 15 & 15 \\
\hline 4 & 2 & 0 & 0 & 0 & 0 & 0 & 0 & 0 & 0 & 0 \\
\hline 5 & 1 & 0 & 0 & 0 & 0 & 0 & 0 & 0 & 0 & 0 \\
\hline \multicolumn{2}{|c|}{ Jumlah } & 33 & 138 & 100 & 33 & 134 & 100 & 33 & 129 & 100 \\
\hline \multirow[t]{3}{*}{ No } & \multirow[t]{3}{*}{ Bobot } & \multicolumn{9}{|c|}{ Variabel efektivitas pelayanan } \\
\hline & & \multicolumn{3}{|c|}{ Item 1} & \multicolumn{3}{|c|}{ Item 2} & \multicolumn{3}{|c|}{ Item 3} \\
\hline & & $\mathrm{F}$ & Skor & $\%$ & $\mathrm{~F}$ & Skor & $\%$ & $\mathrm{~F}$ & Skor & $\%$ \\
\hline 1 & 5 & 7 & 35 & 21 & 6 & 30 & 18 & 3 & 15 & 10 \\
\hline 2 & 4 & 24 & 96 & 72 & 24 & 96 & 72 & 20 & 80 & 60 \\
\hline 3 & 3 & 2 & 6 & 7 & 3 & 9 & 10 & 10 & 30 & 30 \\
\hline 4 & 2 & 0 & 0 & 0 & 0 & 0 & 0 & 0 & 0 & 0 \\
\hline 5 & 1 & 0 & 0 & 0 & 0 & 0 & 0 & 0 & 0 & 0 \\
\hline \multicolumn{2}{|c|}{ Jumlah } & 33 & 137 & 100 & 33 & 135 & 100 & 33 & 125 & 100 \\
\hline
\end{tabular}

\begin{tabular}{|c|c|c|c|c|c|c|c|c|c|c|}
\hline \multirow{2}{*}{ No } & \multirow{2}{*}{ Bobot } & \multicolumn{8}{|c|}{ Variabel efektivitas pelayanan } \\
\cline { 2 - 12 } & & \multicolumn{3}{|c|}{ Item 1 } & \multicolumn{3}{c|}{ Item 2 } & \multicolumn{3}{c|}{ Item 3 } \\
\cline { 2 - 12 } & $\mathrm{F}$ & Skor & $\%$ & $\mathrm{~F}$ & Skor & $\%$ & $\mathrm{~F}$ & Skor & $\%$ \\
\hline 1 & 5 & 4 & 20 & 12 & 7 & 35 & 21 & 6 & 30 & 18 \\
\hline 2 & 4 & 24 & 96 & 73 & 17 & 68 & 51 & 21 & 84 & 64 \\
\hline 3 & 3 & 5 & 15 & 15 & 9 & 27 & 28 & 6 & 18 & 18 \\
\hline 4 & 2 & 0 & 0 & 0 & 0 & 0 & 0 & 0 & 0 & 0 \\
\hline 5 & 1 & 0 & 0 & 0 & 0 & 0 & 0 & 0 & 0 & 0 \\
\hline \multicolumn{2}{|c|}{ Jumlah } & 33 & 131 & 100 & 33 & 130 & 100 & 33 & 132 & 100 \\
\hline
\end{tabular}

Sumber : Data diolah, 2019 
Berdasarkan tabel di atas, data item (no.1) yang diperoleh dari 33 responden, mendapat skor 138, tergolong tinggi. Data item (no.2), mendapat skor 134, tergolong tinggi. Data item (no.3) mendapat skor 129, tergolong sangat tinggi. Data item (no.4), mendapat skor 137, tergolong tinggi. Data item (no.5) mendapat skor 135, tergolong sangat tinggi. Data item (no.6) mendapat skor 125, tergolong tinggi. Data item (no.7) mendapat skor 131, tergolong tinggi. Data item (no.8) mendapat skor 130, tergolong sangat tinggi. Data item (no.9) mendapat skor 132, tergolong tinggi. Hal ini menunjukkan bahwa kemampuan pegawai dalam melaksanakan tugas yang diberikan oleh pimpinan merupakan tanggung jawabnya

\section{Analisis Data Statistik.}

Untuk mengetahui pengaruh iklim organisasi terhadap efektivitas kerja pegawai pada Kantor Camat Kota Utara Kota Gorontalo..maka berikut ini akan dikemukakan analisis hasil statistk. Berdasarkan hasil analisis diketahui bahwa variabel-variabel bebas (Independen) memberikan pengaruh yang nyata (signifikan) terhadap variabel terikat (dependen). Hasil olahan data kerangka hubungan kausal antara X1,X2 dan X3 tehadap Y dapat dibuat melalui persamaan struktural sebagai berikut :

$$
\mathrm{Y}=0,425 \mathrm{X} 1+0,380 \times 2+0,323+0,201 \mathrm{e}
$$

Dari persamaan diatas, menunjukkan bahwa koefisien variabel independen dapat dijelaskan sebagai berikut :

1. Variabel tanggung jawab (X1) sebesar 0,425 dan bertanda positif, menandakan variabel tanggung jawab (X1), memiliki kontribusi yang positif terhadap efektivitas pelayanan pegawai (Y). Artinya, bahwa apabila tanggung jawab meningkat satu satuan, maka efektivitas pelayanan pegawai $(Y)$ meningkat sebesar 0,425 Besarnya kontribusi variabel tanggung jawab yang secara langsung berkontribusi terhadap efektivitas pelayanan pegawai $(\mathrm{Y})$ sebesar 0,425 atau $42,5 \%$

2. Variabel Ipenghargaan (X2) sebesar 0,380 dan bertanda positif, menandakan variabel penghargaan (X2), memiliki kontribusi yang positif terhadap efektivitas pelayanan pegawai $(\mathrm{Y})$. Artinya, bahwa apabila variabel penghargaan meningkat satu satuan, maka efektivitas pelayanan pegawai $(\mathrm{Y})$ meningkat sebesar 0,380 Besarnya kontribusi variabel penghargaan yang secara langsung berkontribusi terhadap efektivitas pelayanan pegawai $(\mathrm{Y})$ sebesar 0,380 atau $38,0 \%$

3. Variabel dukungan (X3) sebesar 0,323 dan bertanda positif, menandakan variabel dukungan (X3), memiliki kontribusi yang positif terhadap efektivitas pelayanan pegawai (Y). Artinya, bahwa apabila variabel dukungan meningkat satu satuan, maka efektivitas pelayanan pegawai $(\mathrm{Y})$ meningkat sebesar 0,323 Besarnya kontribusi dukungan yang secara langsung berkontribusi terhadap efektivitas pelayanan pegawai $(\mathrm{Y})$ sebesar 0,323 atau $32,3 \%$

4. Epsilon (e) sebesar 0,201 menunjukkan bahwa terdapat variabel - variabel lain yang tidak diteliti dalam penelitian ini sebesar $20,1 \%$

5. Koefisien Determinasi ( $R$ Square). sebesar 0,799, menunjukkan bahwa variabel tanggung jawab,penghargaan dan dukungan memiliki pengaruh secara bersama terhadap efektivitas pelayanan pegawai pada Kantor Camat Kota Utara Kota Gorontalo serta masih ada sekitar $21,1 \%$ ditentukan oleh variabel lain yang tidak diteliti dalam penelitian ini, misalnya disiplin kerja pegawai 
Berdasarkan hasil olahan data yang mengunakan analisis jalur hubungan antar variabel dapat dilihat pada gambar di bawah in:

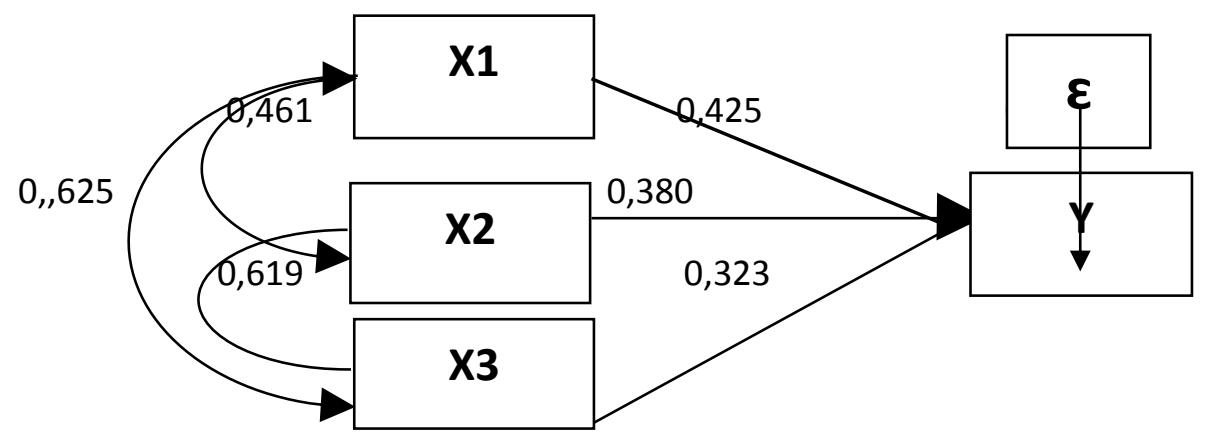

Gambar 2. Hubungan antara X1 dan X2 terhadap Y

Sumber : Diolah dari data penelitian

Kemudian Hasil penelitian di atas dapat diringkas seperti pada Tabel 4.11 sebagai berikut

Tabel 11 : Koefisien jalur, pengaruh langsung, pengaruh total variabel (X1) dan (X2) secara simultan dan signifikan terhadap $(Y)$

\begin{tabular}{|c|c|c|c|c|}
\hline Variabel & \multirow{2}{*}{$\begin{array}{c}\text { Koefisien } \\
\text { Jalur }\end{array}$} & \multicolumn{2}{|c|}{ Kontribusi } & \multirow{2}{*}{$\begin{array}{c}\text { Kontribusi Bersama } \\
\left(\mathbf{R}^{2} \mathbf{y x 1 \times 2}\right.\end{array}$} \\
\cline { 3 - 4 } & 0,425 & 0,425 & $42,5 \%$ & \multirow{2}{*}{$0,799(79,9 \%)$} \\
\hline $\mathrm{X} 1$ & 0,380 & 0,380 & $38,0 \%$ & \\
\hline $\mathrm{X} 3$ & 0,323 & 0,323 & $32,3 \%$ & \\
\hline $\mathrm{E}$ & 0,201 & 0,201 & $20,1 \%$ & \\
\hline
\end{tabular}

Sumber : Hasil pengolahan data peneliti,2019

\section{Pengujian Hipotesis}

Iklim Organisasi secara simultan berpengaruh signifikan terhadap Efektivitas pelayanan $(\mathrm{Y})$.

Dari hasil pengolahan data dengan menggunkana program SPSS vs 21.0 , uji siginifikansi analisis jalur dengan membandingkan antara probabilitas 0,05 dengan probabilitas sig dengan dasar pengambilan keputusan bahwa jika nilai probabilitas alpha $(0,05)$ lebih bear atau sama dengan nilai probabilitas sig $(0,05<$ sig), atau jika nilai $F$ hitung > nilai $\mathrm{F}$ tabel maka Ha diterima, artinya signifikan,

Dari hasil olahan data diperoleh nilai sig $\mathrm{F}$ sebesar 0,000 dengan nilai probabilitas alpha $(0,05$. Karena nilai alpha $0,05>\operatorname{sig} 0,000$ dan $F$ hitung $(21,678)>F$ tabel $(3,15)$ maka keputusannya adalah Ha diterima sehingga terbukti bahwa variabel iklim organisasi yang terdiri dari tanggung jawab (X1), penghargaan (X2) dan dukungan (X3) secara simultan berpengaruh signifikan terhadap efektivitas pelayanan (Y). 


\section{Tanggung jawab (X1) Secara parsial berpengaruh signifikan terhadap Efektivitas Pelayanan (Y).}

Hasil olahan data diperoleh bahwa tanggung jawab mempunyai nilai sig sebesar 0,000 , kemudian dibandingkan dengan nilai probabilitas 0,05 , ternyata nilai probabilitas 0,05 lebih besar dengan nilia probabilitas sig atau $(0,05>0,000)$ dan nilai $t$ hitung $(15,643)>$ nilai $t$ tabel $(2,042)$, maka Ho ditolak artinya signifikan. Jadi terbukti bahwa tanggung jawab berpengaruh signifikan terhadap efektivitas pelayanan

Penghargaan (X2) Secara parsial berpengaruh signifikan terhadap Efektivitas kerja (Y).

Hasil olahan data diperoleh bahwa penghargaan (X2) memiliki nilai sig sebesar 0,000, kemudian dibandingkan dengan nilai probabilitas 0,05 , ternyata nilai probabilitas 0,05 lebih besar dengan nilia probabilitas sig atau $(0,05>0,001)$ dan nilai t hitung $(8,534)>$ nilai t tabel $(2,042)$ maka Ho ditolak artinya signifikan. Jadi terbukti bahwa Penghargaan (X2) berpengaruh signifikan terhadap efektivitas pelayanan $(\mathrm{Y})$.

Dukungan (X3) Secara parsial berpengaruh signifikan terhadap Efektivitas kerja (Y).

Hasil olahan data diperoleh bahwa variabel dukungan (X3) memiliki nilai sig sebesar 0,000 , kemudian dibandingkan dengan nilai probabilitas 0,05 , ternyata nilai probabilitas 0,05 lebih besar dengan nilia probabilitas sig atau $(0,05>0,001)$ dan nilai t hitung $(7,277)$ $>$ nilai t tabel $(2,042)$ maka Ho ditolak artinya signifikan. Jadi terbukti bahwa dukungan (X3) berpengaruh signifikan terhadap efektivitas pelayanan (Y).

Tabel 12. Pengujian Hipotesis Variabel tanggung jawab,penghargaan dan dukungan terhadap Efektivitas Pelayanan

\begin{tabular}{|c|c|c|c|}
\hline $\begin{array}{c}\text { Pengaruh Antar } \\
\text { Variabel }\end{array}$ & Nilai Sig & Alpha & Keputusan \\
\hline Pyx1Pyx2 & 0,000 & 0,05 & Signifikan \\
\hline Pyx1 & 0,000 & 0,05 & Signifikan \\
\hline pyx2 & 0,001 & 0,05 & Signifikan \\
\hline Pyx3 & 0,001 & 0,05 & Signifikan \\
\hline
\end{tabular}

Sumber : Hasil pengolahan data peneliti,2019

\section{Pengaruh Iklim Organisasi secara simultan berpengaruh terhadap Efektivitas Kerja Pegawai}

Hasil penelitian ini menunjukkan bahwa terdapat pengaruh yang positif dan signifikan antara iklim organisasi yang meliputi tanggung jawab, penghargaan dan dukungan dan efektivitas pelayanan pegawai. Hal ini memberikan penjelasan bahwa semakin baik iklim kerja yang ada di lingkungan kantor Camat kota Utara Kota Gorontalo maka akan meningkatkan efektivitas kerja pegawai 
Studi empiris mengenai pengaruh terhadap iklim kerja telah dilakukan oleh Lopes (2013) dengan hasil meneliti pengaruh iklim organisasi terhadap efektivitas pelayanan diperoleh kesimpulan bahwa iklim organisasi memiliki pengaruh yang positif dan signifikan terhadap efektivitas pelayanan kerja pegawai Maka dari itu dapat disimpulkan apabila iklim organisasi baik, akan meningkatkan efektivitas pelayanan pegawai

Pelayanan adalah pemberian pelayanan (melayani) keperluan orang lain atau masyarakat yang mempunyai kepentingan pada organisasi itu sesuai dengan aturan pokok dan tata cara yang telah ditetapkan" Jadi pelayanan yang diberikan oleh pemerintah haruslah mendahulukan kepentingan masyarakat dengan waktu yang singkat, mudah serta dapat memberikan rasa puas bagi masyarakat yang menikmati layanan itu. Pendapat lain seperti yang dijelaskan (Kotler (Lukman 2003:4): pelayanan adalah setiap kegiatan yang menguntungkan dalam suatu kumpulan atau kesatuan, dan menawarkan kepuasan meskipun hasilnya tidak terikat pada suatu produk secara fisik" Hasil penelitian ini mengungkapkan bahwa terdapat variabel lain yang turut mempengaruhi variabel kepuasan kerja namun tidak diteliti sebesar 20,1\% misalnya disiplin kerja pegawai. Menurut Nitisemito (2006:199) menyatakan masalah kedisiplinan kerja,merupakan masalah yang perlu diperhatikan, sebab dengan adanya kedisiplinan, dapat mempengaruhi efektivitas dan efisiensi pencapaian tujuan organisasi

\section{Pengaruh Tanggung jawab Terhadap Efektivitas Pelayanan Pegawai}

Hasil penelitian ini menunjukkan bahwa secara parsial terdapat pengaruh yang positif dan signifikan antara iklim organisasi dan efektivitas pelayanan pegawai. Hal ini memberikan penjelasan bahwa semakin besar tanggung jawab yang diberikan kepada pegawai maka akan meningkatkan efektivitas pelayanan kerja pegawai. Penelitian oleh Rendi Putrayana, 2014 Pengaruh iklim organisasi kerja terhadap efektivitas pelayanan Hasil penelitian ini menunjukkan bahwa iklim organisasi berpengaruh signifikan terhadap efektivitas pelayanan Pelayanan yang baik tidak akan dicapai tanpa adanya usaha dari aparat organisasi itu sendiri. Oleh karena itu, untuk dapat mencapai pelayanan yang baik diperlukan kecakapan, ketangkasan, keteraampilan maupun modal lain yang dimiliki oleh aparat. Sedangkan kecakapan, ketangkasan, keterampilan maupun modal lain yang dimiliki oleh aparat disebut dengan kemampuan aparat.

Berdasarkan hasil penelitian ini dapat dijelaskan bahwa dengan adanya tanggung jawab akan dapat meningkatkan efektivitas pelayanan kerja pegawai. Bagi aparat pelayanan publik yang melayani masyarakat, tanggung jawab ini sangatlah dibutuhkan, terutama dalam berkomunikasi dengan cara yang baik dan untuk bisa bekerjasama dengan anggota kelompok lainnya yaitu sesama aparat. Dengan adanya komunikasi yang baik dengan masyarakat pengguna layanan maka akan dapat meningkatkan daya tanggap petugas terhadap keluhan-keluhan ataupun kebutuhankebutuhan masyarakat pengguna layanan yang dapat dijadikan bahan masukan bagi aparat agar dapat melayani masyarakat derngan baik

\section{Pengaruh variabel PenghargaanTerhadap Efektivitas Pelayanan Pegawai}


Penghargaan yaitu perasaan karyawan diberi imbalan yang layak setelah menyelesaikan pekerjaannya dengan baik. meliputi imbalan atau upah yang terima karyawan setelah menyelesaikan pekerjaan. Penghargaan ini meliputi pemberian imbalan tambahan bagi pegawai yang berprestasi. tingkat penghargaan bagi para pegawai yang berprestasi.rasa aman dan nyaman pada saat bekerja .adanya insentif yang sesuai dengan pekerjaannya.

Natalia Buntu Sarira,2014, Pengaruh Kompensasi, lingkungan kerja dan motivasi kerja Hasil analisis membuktikan Variabel Kompensasi mempunyai hubungan yang sangat kuat terhadap motivasi kerja,.

Pemberian penghargaan dikatakan penting, karena pimpinan atau manajer itu tidak sama dengan karyawan, karena seorang pimpinan tidak dapat melakukan pekerjaan sendiri. Keberhasilan organisasi amat ditentukan oleh hasil kerja yang dilakukan orang lain (bawahan).

Penghargaan yang diberikan oleh organisasi dapat dianggap memberikan keuntungan bagi karyawan, seperti adanya perasaan diterima dan diakui, memperoleh gaji dan promosi, mendapatkan akses-akses informasi, serta bentuk-bentuk bantuan lain yang dibutuhkan karyawan untuk dapat menjalankan pekerjaannya secara efektif. Terdapatnya norma timbal balik ini menyebabkan karyawan dan organisasi harus saling memperhatikan tujuan- tujuan yang ada dalam hubungan kerja tersebut (Rhoades \& Eisenberger, 2002)

\section{Pengaruh DukunganTerhadap Efektivitas Pelayanan Pegawai}

Pelayanan yang menyeluruh tidak hanya muncul dari kontribusi-kontribusi individual para karyawan. Keterpaduan antar semua komponen sangat dibu- tuhkan untuk mencapai kualitas yang maksimal. Selain itu, perilaku untuk saling membantu, mendukung rekan kerja, dan bertanggung jawab secara menyeluruh pada organisasi, meski bukan merupakan tugas yang telah digariskan, sangat menentukan kinerja organisasi.

Hasil penelitian ini memeiliki pengaruh positif dan signifikan terhadap efektivitas pelayanan pegawai pada Kantor Camat Kota Utara Kota Gorontalo, namun variabel ini memiliki pengaruh yang lebih kecil dibanding dengan variabel lainnya yaitu tanggung jawab dan penghargaan, hal ini disebabkan karena menurut wawancara dengan informan, keefektifan pegawai dalam melaksanakan tugasnya sangat penting dalam melaksanakan tugasnya sebagai pelayan masyarakt, akan tetapi kadang - kadang pegawai kurang memberikan dukungan dalam hal partisipasi pegawai dalam mengambil keputusan. dan mengambil tindakan dalam situasi darurat. peraturan belum sepenuhnya dilajankan dengan baik, sehingga mempengaruhi tugas - tugasnya dalam melayani masyarakat

\section{Kesimpulan}

Berdasarkan hasil penelitian yang telah dilakukan sehubungan dengan pengaruh Iklim organisasi terhadap efektivitas pelayanan pegawai pada Kantor Camat 
Kota Utara Kota Gorontalo, maka penulis dapat menarik beberapa kesimpulan sebagai berikut :

1. Berdasarkan hasil uji $F$ secara simultan iklim organisasi yang terdiri dari tanggung jawab, penghargaan dan dukungan memiliki pengaruh yang positif dan signifikan terhadap efektivitas pelayanan kerja pegawai.

2. Tanggung jawab memiliki pengaruh yang positif dan signifikan terhadap efektivitas pelayanan kerja pegawai. Hal ini menunjukkan bahwa semakin tinggi pemberian kompensasi, akan meningkatkan efektivitas pelayanan pegawai .

3. Penghargaan memiliki pengaruh yang positif dan signifikan terhadap efektivitas pelayanan kerja pegawai. Hal ini menunjukkan bahwa dengan adanya penghargaan yang diberikan oleh pimpinan, maka akan meningkatkan efektivitas pelayanan pegawai

4. Dukungan memiliki pengaruh yang positif dan signifikan terhadap efektivitas pelayanan kerja pegawai. Hal ini menunjukkan bahwa dengan adanya dukungan dari pimpinan, maka akan meningkatkan efektivitas pelayanan pegawai

\section{Saran}

Dari kesimpulan di atas, untuk mecapai maksud dan tujuan peningkatan efektivitas pelayanan pegawai Kantor Camat Kota Utara Kota Gorontalo, maka disarankan kepada pimpinan:

1. Mengacu pada hasil penelitian ini, dari dvariabel bebas maka diketahui variabel dukungan memiliki pengaruh yang lebih kecil dibanding variabel lainnya, oleh karena itu itu pimpinan di lingkungan Kantor Camat Kota Utara Kota Gorontalo hendaknya memberikan dukungan kepada pegawai agar dapat bekerja termotivasi yang pada akhirnya efektivitas pelayanan dapat ditingkatkan, seperti dukungan untuk menngikutsertakan para pegawai mengikuti pelatihan.

2. Bagi penelitian yang akan datang disarankan agar menggunakan variabel lain yang dapat mempengaruhi efektivitas pelayanan misalnya disiplin kerja Menurut Nitisemito (2006:199) menyatakan masalah kedisiplinan kerja,merupakan masalah yang perlu diperhatikan, sebab dengan adanya kedisiplinan, dapat mempengaruhi efektivitas dan efisiensi pencapaian tujuan organisasi 


\section{DAFTAR PUSTAKA}

Arikunto, 2003. Metodologi penelitian. Penerbit Gramedia. Jakarta.

Davis K. dan Newstrom W. 1985. Human Behavior at work: Organizational, sevent edition. Mc. Graw Hill Inc. Terjemahan Agus Dharma. Perilaku dalan Organisasi. Penerbit Erlangga, Jakarta.

Gibson, Ivancevic, dan Donnely. 1997. Organisasi dan Manajemen. Penerbit Erlangga, Jakarta.

Handoko, T. Hani, 1999. Manajemen. Penerbit BPFE, Yogyakarta.

Handoko, T. Hani, 2000. Manajemen Personalia dan Sumber Daya Manusia. Penerbit BPFE, Yogyakarta.

Http://digilib.petra.ac.id/2005, 29 januari 2010.

Hasibuan,S.P. Malayu, 2002. Manajemen Sumber Daya Manusia. Edisi revisi, Penerbit PT. bumi Aksara, Jakarta.

Kuncoro, Mudrajad, 2003. Metode Riset untuk Bisnis \& Ekonomi. Penulis Erlangga. Jakarta.

Moenir, 2010. Manajemen Pelayanan Umum di Indonesia. Penerbit Pt. Bumi Aksara, Jakarta.

Nitisemito,Alex. S. 2006. Manajemen Personalia. Penerbit Ghalia, Jakarta.

Steers, M.Richard, 1999. Modern Human Relations At Work. Fort Worth. the Dryden Press.

Riduwan, 2005. Metode dan Teknik penyusunan Tesis. Penerbit Alfabeta, Bandung.

Ruswati, 2005. Pengaruh Disiplin dan Iklim Kerja terhadap Efektivitas Pelayanan aparat Pemerintah Kecamatan cilacap Utara. Skripsi, Kab. Cilacap.

Sugiyono. (2010). Metode Penelitian Bisnis. Bandung: Alfabeta.

2016. Statistika Untuk Penelitian Kuantitatif, Kualitatif dan R\&D. Bandung: Alfabeta

Siagian, Sondang P. 1988. Sistem Informasi untuk Pengambilan Keputusan. Penerbit CV. Haji Masagung, Jakarta.

Simamora, Henry.2001. Manajemen Sumber Daya Manusia. Edisi Kesatu, STIE YKPN, Yogyakarta.

Wirawan, 2012, Dasar - Dasar ilmu Organisasi, Andi Yogyakarta 